\title{
Brief Analysis on the Application of Flipped Classroom in Entrepreneurship Education
}

\author{
Wensheng Wang ${ }^{1, a}$ and Haibo Wang ${ }^{1, b}$ \\ ${ }^{1}$ Jingdezhen Ceramic Institute Jingdezhen City, Jiangxi Province, China \\ a344239916@qq.com, ${ }^{\mathrm{b}} 516724119 @ q q . c o m$
}

Keywords: Flipped Classroom; Entrepreneurship Education; Application Techniques

\begin{abstract}
The twenty-first century is the era of knowledge economy, and the core is entrepreneurial economy. How to facilitate the innovative entrepreneurial education, improve its education quality has always been the mission for college teachers. Flipped classroom will change the traditional role, learning space, teaching procedure of teachers and students, which will inevitably strengthen interaction and create personalized education. As a result, students will take the initiative to learn. So far, the flipped classroom has receive high attention from a glittering array of educators. How to better apply the flipped classroom in entrepreneurship education is the key that we have to think about and pay attention to.

Along with the popularization of modern media including internet+, intelligent campus and mobile APP, college educators begin to pursue the innovative teaching methods reform by adopting new media and technology. Flipped classroom has innovated the teaching philosophy, procedure, methods and stimulated the passion of students as well as the creativity of teachers, which has also extended the time and space of teaching and will definitely lead to the improvement of learning efficiency and quality. Entrepreneurship education aims to cultivate the entrepreneurship consciousness, skills and eagerness. What's more, Ministry of Education launched A Notice on the Employment and Entrepreneurship for Undergraduates in 2015 has asked colleges to promote higher education reform and fully strengthen innovative and entrepreneurship education. Therefore, we have to apply the flipped classroom to entrepreneurship, strengthen the interaction while learning so as to strengthen its reform.
\end{abstract}

\section{The Connotation and Advantages of Flipped Classroom}

Flipped classroom or inverted classroom was originated in America in 2007. Jonathan Bergmann and Aaron Sams from WoodlandPark High School adopted video software to record PPT with voice explanation to help students catch up the class they missed. So-called flipped classroom is to convey knowledge by watching videos before class. In class, teachers will help students to have a deeper understanding. In addition, flipped classroom is able to adjust the internal and external time so as to make students take the initiative, which is a new teaching mode. Moreover, with the development and popularization of the internet, the flipped classroom prevails.

Flipped classroom is a fundamental change comparing to traditional classroom, which completely changed the roles of teachers and students and can realize the teaching philosophy as well as interaction.

To begin with, flipped classroom is conducive to ignite the enthusiasm of students, which can vividly explain the questions based on pictures, voice and video and thus to help students better understand the knowledge. What's more, students can take advantage of the mobiles and computers to make a pre-study according to their learning schedule. Moreover, by repeatedly watching the videos they recorded, they are able to improve learning efficiency and effect.

What's more, flipped classroom is beneficial to teach students according to their aptitude and carry out personalized education. Students can repeatedly watch videos until they totally understand the point. In class, students can also express their confusions and ask teachers to help them solve the problems based on individualized tutoring. 
Last but not the least, flipped classroom is beneficial to cultivate students' innovative and entrepreneurship ability. If we only focus on theoretical knowledge conveying, it will be difficult for teachers to understand the fun of entrepreneurship education but discourage students. Comparing to traditional learning, the combination of flipped classroom and entrepreneurship education can help students re-construct the learning contents and space, directly understand its theory and practice, optimize learning methods and improve students' ability to find problems, analyze problems and solve problems.

\section{The Correlation Between Flipped Classroom and Entrepreneurship Education}

In terms of education philosophy: flipped classroom advocates the core role of students and encourages them to learn independently while teachers only play the role as organizers and leaders. Traditional teaching methods emphasize on the core role of teachers and students learn passively. The combination of flipped classroom and entrepreneurship education changed the traditional idea and encourages students to take the initiative to learn and can improve their abilities.

In terms of education methods: in traditional entrepreneurship classes, students feel boring and inefficient and they don't have any passion for learning, because it cannot satisfy their needs. As a result, they don't focus on study and become rebellious. Flipped classroom focuses on after-class activities and changes the cramming method. In addition, there are interactions as well as communications between them. As a result, teachers can timely have a general idea of their learning condition and guide them to develop properly.

In terms of education objects: Students born after 1990 are exposed to a pluralistic society and they are very independent. Therefore, traditional cramming method will discourage them and make them rebel. Flipped classroom adopts personalized teaching methods and management methods, which can encourage students to make good for deficiency.

In terms of education resources: nowadays, technology is changing fast and people can get information from various sources. We can simply conclude that the world will be connected if there is an internet. In 2002, China began to carry out entrepreneurship education however the faculties quality and teaching materials are varied. Teachers can record videos and choose proper subjects to make students learn independently. Moreover, students can also choose videos by themselves to learn because they get access to the best sources owing to the development of internet.

\section{How to Adopt Flipped Classroom in Entrepreneurship Education}

Entrepreneurship education can adopt flipped classroom mode so as to make students learn the video before class and interact during class based on interest-driven mode, which will inevitably create a happy environment for students. The following discusses how can we adopt flipped classroom in entrepreneurship education from a macro and micro perspectives. The macro perspective takes teaching contents, teaching platform and teaching design into consideration:

Concerning modularized teaching contents. Teaching materials are important carriers and different teaching materials have different philosophies, knowledge systems and logic structures. In the premise of guaranteeing a comprehensive and scientific knowledge system, we can actually organize different teaching materials. For example, in terms of entrepreneurial team teaching, we can set four modules including: team concept, characteristics of excellent teams; construction steps of a team, team conflict solution.

Establish an online interaction platform after class. Flipped classroom demonstrates the knowledge and encourages students to apply knowledge. In addition, teachers can establish interactive online learning platform including official wechat, blog, QQ group and mobile APP, share teaching powerpoint, video and sources so that students can finish basic learning by themselves. In the meanwhile, students and teachers can carry out communications via this online platform.

Establish an interactive group for problems solving. Flipped classroom asks students to prepare before class. However, students do not know how to deeply dig into the topic. Therefore, teachers 
should set a series of problems in advance and provide students with materials. In addition, students should pay attention to these materials and look up the answers so as to understand the knowledge better. In class, teachers can also carry out personalized tutoring for those problems which have not been solved yet to improve the effectiveness of learning.

The micro perspectives takes into learning tasks, video recording and classroom organization into consideration:

Design an independent learning task list, including core points, ability targets, learning suggestions, learning length, puzzles etc. In addition, teachers should assign learning tasks before class and ask students to watch teaching videos or related videos so as to finish knowledge conveying. During this process, students can write down the questions and complete the assignment. In order to encourage students watch the video materials, the pre-class assignment will be calculated into the credits to stimulate students' passion. We can conclude that the design and application of learning task list is the key for successfully establish flipped classroom. Meanwhile, it can also test the ability of teachers.

Record videos and take different topics as units. Video is deemed as an important carrier of flipped classroom. While recording the videos, we have to clear the topic first. In addition, we should record based on a different knowledge topic and control the record time in 10 minutes; secondly, the video should be rich in contents with vivid pictures and we can edit based on sound, light and electric and take the education background, learning time and video watching methods into consideration so as to show a fantastic one. For example, the videos should be titled, words should be added along with graphs and pictures with sound, which should be smoothly related to each other and create a complete system. Based on that, students will constantly learn and relate the knowledge.

Effectively guide group discussion. How to guide students to fully express themselves and understand the knowledge should be the core of flipped classroom. Flipped classroom does not only ask teachers to carry out personalized explanation but also effectively organize students to participate in the class to solve problems. For example, while talking about the topic of selecting the location of a company in class, we should divide the classroom into different groups and teachers should supervise and solve their puzzles to create a vivid class. In the last stage of the classroom, teachers should raise a question and give a conclusion to cultivate students' ability to demonstrate themselves.

\section{Acknowledgement}

This paper is the result of Teaching reform carried out in 2014 Jiangxi (Research and practice of cultivating talents regarding entrepreneurship-Take Jingdezhen Ceramics Institute as an example); 2015 Jiangxi Higher Education Reform Program (research and practice of cultivating talents regarding entrepreneurship, innovation and excellence-creating)

\section{References}

[1] Wang Pan, Zheng Yanping, Lu Chang. New opportunities for entrepreneurship education brought by flipped classroom [J] Vocational education. 2015.11

[2] Wang Zaorong, Zhao Xinyu. The necessity of applying flipped classroom in college ideological and political class-take Maoism and Socialism with Chinese Characteristics Theories as example [ J ] Journal of Wuhan Metallurgical Manager's Institute. 2015.6

[3] Zhu Jianfeng. A comparative study on flipped classroom and rational teaching mode [J] Journal of Beijing City University. 2015.5

[4] Tang Min. Application of flipped classroom in online business [ $\mathrm{J}$ ] The Light \& Textile Industries of Fujian. 2014.11

[5] Lin Jiangmei. The application of flipped classroom in college ideological and political classroom $[\mathrm{J}]$. Communist party construction and ideological \& political education. 2014.11 
[6] Xu Jin. Application and thought of flipped classroom in vocational schools [ J ] . China Education Information. 2014.12

[7] Yu Ping. Application of flipped classroom in English teaching [J] Journal of teaching and management. 2014.9

[8] Zhao Xinglong. Knowledge internalization and teaching mode design in flipped classroom [J] . Modern distance education research. Term 22014 